Article

\title{
Teaching Using Digital Technologies: Transmission or Participation?
}

\author{
Maria Cutajar $\mathbb{D}$ \\ Faculty of Education, University of Malta, 2080 Msida MSD, Malta; maria.cutajar@um.edu.mt
}

Received: 3 July 2019; Accepted: 22 August 2019; Published: 28 August 2019

\begin{abstract}
Digital technologies are becoming seamlessly incorporated in all we do, no less in teaching and learning. As technological developments and interdependent social change steer us deeper into a postdigital existence, higher education institutions are observed increasing the availability of learning technologies and related academic development initiatives. Alongside these developments, models of teaching as transmission are popularly criticized and set in contrast to models of teaching as participation, which are commended and avowed as more suited for the present day digital university. This paper presents the research findings of a qualitative study, which was specifically taken up in response to observed developments. The findings derive from phenomenographic analysis mapping variation in the accounts of 27 academics describing their experiences using digital technologies for teaching. These results represent a wide-ranging description confirming previous research findings and add new detail. They reaffirm teaching orientations of transmission and participation as important and significant facets of teaching moreover existing claims based on logical argumentation. These research results potentially serve professional development constructively supporting academics seeking to incorporate contemporary digital technologies in their teaching practices.
\end{abstract}

Keywords: teaching; higher education; digital education; phenomenography

\section{Introduction}

Digital technologies are being seamlessly incorporated in all we do. While technological developments (such as social media, immersive technologies, the Internet of Things (IoT) and artificial intelligence (AI)) and interdependent social change continue to steer us deeper into a postdigital existence [1], in the educational field higher education (HE) institutions are observed increasing the availability of learning technologies and related academic development services [2-4]. Often, this drive is seen as adding to the pressure on teaching academics to adopt and adapt [5]. Calls for the disruption and the transformation of teaching through technology use abound [6-10] along with declarations that the use of digital technologies for knowledge dissemination purposes is ineffective $[9,10]$. Attention is drawn to the multi-media and multi-modal communication potential of contemporary digital technologies for teaching and learning activity [11-13]. The use of digital technologies for knowledge transmission is popularly set out in contrast to what is seen as the alternative view of teaching as participation, which is flagged as more suited to '21st century learning' requirements [8,9]. The long-standing debate on teaching and learning as transmission of knowledge as opposed to teaching and learning as participation for knowledge cocreation [14] continues in earnest notwithstanding the judicious appeals of education specialists [15-17] advising caution. Within the wider educational body of literature, the claim for the concurrence of transmission and participation oriented strategies in teaching practice can be traced back to Sfard [14] who, from a learning perspective, used logical argumentation to show up the "acquisition metaphor (AM)" and the "participation metaphor (PM)" as both important for learning. Recently, Eynon and Salveson [18] raised the issue again with reference to the role of AI for learning because, from their empirical 
research work, it emerged that so far innovation in this area is attending mostly to the knowledge dissemination aspect. They urge more nuanced and balanced engagement. The research presented in this paper considers contemporary digital technologies more generally by focusing on variation in how academics are experiencing them for teaching. It presents the research findings of a phenomenographic study, which led to the constitution of a comprehensive map of qualitative distinctions in HE teaching using digital technologies. This research outcome is seen giving a new strength to the argument underscoring transmission and participation teaching orientations as important facets of teaching. The all-inclusive perspective advanced by this research outcome is a constructive means to support academics in developing teaching practice incorporating digital technologies.

Structurally the paper is comprised of three sections. The Section 1 briefly considers background and previous literature. The Section 2 outlines the qualitative study taken up in response to the intensifying institutional drive encouraging academics to incorporate available digital technologies in their teaching practices. The Section 3 discusses the research results of this study. There is shared how the research outcomes can serve individual and collective efforts in seeking to develop teaching mediated by digital technologies. There is also clarified how these findings build on the case for the distinct transmission and participation oriented teaching strategies to be recognized as important and significant facets of HE teaching. This paper is a development of the work presented by the research author during the last biennial international conference on networked learning [19]. Cutajar [20] presents the full research project report.

\section{Teaching Using Digital Technologies}

In teaching and learning, contemporary and emergent digital technologies such as social media, immersive technologies and AI applications enable multi-way and multi-modal communication flexibly and seamlessly connecting students, teachers and resources. Leading researchers in the field of digital education talk about "assemblages" [17,21,22] so emphasizing the multiplicity of connectivity possibilities for learning. Gourlay and Oliver [17] report that learning at the "digital university" is comprised of "complex entanglements with non-human devices, objects, digital and analogue texts, spaces and time" creating what they call "fluid assemblages of practice" (p. 9). Learning is emphasized as emergent [21] and correspondingly in teaching we can only design for learning [21,23,24]. Laurillard [25] remarks that teaching is "essentially a rhetorical activity to create the environment that enables students to embrace the twin poles of experiential and formal knowledge" (p. 23). Often, teaching mediated by digital technologies is promoted as shifted from teacher-centered methods underscored as typically consisting of instruction and information propagation to passive student recipients.

\subsection{Thinking about Teaching Using Digital Technologies}

Eager digital education forerunners have long been advocating the transformation of teaching and the disruption of traditional teaching methods using digital technologies $[6,8,9,21,22]$. Teacher-centered transmission models are purported as not fit for the purposes of 21st century learning [10,23]. Bates [9] stresses that "Traditional classroom teaching, and especially transmissive lectures, were designed for another age we are now in a different age that requires different methods" (p. 125). Passionate innovators dismiss transmissive teaching methods as ineffective in consideration of the vast databases of information and other resources available online [26,27]. Promoting connectivism, Siemens [28] argues that, in order to help prepare learners for tomorrow, the educator's role needs to change coming close to be a network administrator, concierge, curator and atelier. Jenkins, Ito and Boyd [29] recently also called to attention the "participatory culture", which is much more visible with social media development. They note the impact of social media on all aspects of our lives and urge educational institutions to engage with digital technologies for advancing learning through social connections and participatory practices. In consideration of unrelenting techno-social change, online and blended active participation learning practices and related student-centered pedagogies are increasingly reckoned to be 
more suited for the purposes of present and future individual and collective learning development [23]. Teaching using digital technologies is promoted by active student engagement in online groups, communities and more recently teacher-student partnerships [30-32]. Teacher-student partnerships, or "students as partners" [30] is a learning approach that is increasingly attracting attention for HE teaching. Emphasizing teacher agency alongside learner agency in formal teaching and learning settings, Biesta [15] critically draws attention to being 'taught by' differentiated from 'learning from', what he refers to as "the gift of teaching" and the need for learners' openness to accept it. In general the judicious drift is for the adoption of teaching as participation more over transmission and instruction.

\subsection{The Need for Critical Inquiry on Teaching Using Digital Technologies}

In consideration of observed harsh criticism regarding persistence with transmission oriented strategies in using digital technologies for teaching, Selwyn [16] recommends that we attend to teachers' reasons into how they use digital technologies for teaching. He recommends critical inquiry substituting "teacher bashing". Gourlay and Oliver [17] also advice caution in view of radical narratives that propose "a complete rejection of academic expertise, established canons of knowledge, disciplinarily or any form of teaching" (p. 21). They argue that "if students are unable to interact critically with experts, data, texts or bodies of knowledge accumulated over the centuries, it is difficult to see what this form of engagement would consist of, or how it would build on or present meaningful or fundamental challenges to what has come before" (p. 21). Likewise, Biesta [15] calls to attention constructivist narratives that write out the teacher from the equation. He argues that "teachers are not disposable and dispensable resources for learning" but need to be valued as a means for learning not necessarily that which is desired but that which is desirable (p. 12). Selwyn [16] notes that "even the most exploratory and collaborative forms of learning as participation require leadership and governance. Anything that students 'participate' in usually needs to be orchestrated and scaffolded by more capable and knowledgeable others" (p. 118). The concerned explorative study, investigating qualitative differences in the experience of using digital technologies for HE teaching, was intentionally taken up to gain an understanding of academics' sensing-making as Selwyn [16] suggests, and possibly make visible teachers' attempts to what Biesta [15] calls "the gift of teaching" in today's world permeated by digital technologies. From the beginning, the research was planned to investigate how the teacher agency is playing out at an institution that is increasingly a digital university $[17,33]$. The research was purposely taken up as a developmental research enterprise [34,35] for the support of academic development. It was this research enterprise that, apart from adding new detail to the emergent research-backed picture of teaching using digital technologies, also led to the delineation of transmission and participation strategies as both important and significant constituent aspects of teaching practice.

\subsection{Previous Studies on Variation in Teaching Using Digital Technologies}

Unearthed previous studies on variation in teaching using digital technologies all come past the commercialization of the Internet and the development of the web as an application of this global digital network. Earlier studies investigated the teaching practices of university lecturers [11,36,37]. Recently there emerged studies focusing on teachers in the vocational education setting [38] and teachers in the compulsory school setting $[39,40]$. Some studies bring in teachers from across different discipline areas $[37,38,41]$. Others consider teachers teaching specific disciplinary subjects. For example, Souleles [42] attends to university teachers of art and design, Lameras, Levy, Paraskakis, and Webber [36] focus on university teachers of computer science, and Waight, Liu, Gregorius, Smith, and Park [40] have been investigating chemistry, primary-school teachers teaching on a specific course unit. Studies generally confirm a pattern of variation in the use of technologies for teaching ranging from access and accumulation of subject content to mobilizing the communicative nature of digital technologies to build a learning support network for students' learning. This pattern matches the information transmission/teacher-focused approaches differentiated from conceptual change/student-focused 
approaches to university teaching generally [43], and in a sense reinforces the popular viewpoint of transmission as opposed to participation orientated teaching practices. The phenomenographic study presented in the next section incorporated a directed effort to explore the relativity and relatedness of different ways of experiencing teaching using digital technologies. This emphasis is not seen so explicitly in similar studies of variation. In this study, variation in experience is described by inclusive distinct categories overarchingly structured by emergent discernment. The achieved configuration is emphasized as a mapping of the constitution of experience [44] rather than some classification of different experiences for labeling experiencers. The next section outlines this research study, especially the results achieved.

\section{The Study of HE Teachers' Experiences}

This phenomenographic approach was taken up for gaining an understanding of how the HE academic experiences using digital technologies for teaching. The phenomenographic approach acts like a prism for generating a spectrum of variation describing the constitution of experience from the perspective of others [45]. The spectrum of variation consists of a parsimonious set of 'categories of description' [46] describing distinct ways of interpreting the experience of the phenomenon studied. These categories of description are structurally related by the commonality of the phenomenon described [47]. They are brought together to form a complete picture by dimensions of deepening discernment, or what Åkerlind [47] refers to as "themes of expanding awareness". As a specific interpretation constituted from a single dataset, the resultant picture is acknowledged as open, even if in practice repeated studies show up a high degree of convergence [46].

\subsection{Research Methods}

For accomplishing this phenomenographic representation of the constitution of experience, data for the concerned study was generated by individual interviews with 27 consenting academics from across a single university complex in a small Southern European country. This educational institution incorporates several disciplinary faculties, a number of interdisciplinary institutes and centers, special-purpose schools and a post-secondary college. The resulting group of research participants was balanced in terms of gender, age, academic status, rank, tenure, disciplinary specialism, teaching experience at different educational levels and engagement incorporating digital technologies in professional practice. Interviews were carried out in the first quarter of the year 2016. Participants were invited to describe personal experiences of teaching using digital technologies including, but not limited to, Internet-based technologies. Neutral questions were also used in an attempt to close in on participants' understanding, intentions and how what they described was seen as supporting students' learning. In preparation for data analysis, the recorded interviews were transcribed verbatim. The data analysis process spread across a period of 8 months. During the earlier stages of analysis, qualitative data software was used to annotate the transcripts and to mark relevant excerpts. However, generally, the iterative process of phenomenographic data analysis was a manual effort. The dataset for the earlier iterations comprised all whole transcripts. For later iterations, the dataset was limited to the resultant pool of relevant excerpts accumulated from the previous iterations. Through each iteration of phenomenographic analysis, the dataset was read several times as a single collection and excerpts sorted for devising the next set of distinct interpretations of using digital technologies for teaching. The earlier iterations of data analysis were focused on identifying differences and commonalities in the dataset towards the construction of the next set of phenomenographic categories of description. As the set of categories of description stabilized when past the fourth iteration, the effort was also directed at configuring the structuring dimensions of deepening discernment bringing together the categories so forming an inclusive hierarchical whole picture. This phenomenographic data analysis was done by a single researcher but in follow-up the results and the pool of transcript excerpts were passed on to another phenomenographer external to this work for validation purposes. 


\subsection{Research Findings}

Figure 1 presents the phenomenographic outcome space constituted from the accounts of participating academics on their experiences using digital technologies in teaching practice. Variation is constituted by five, hierarchically inclusive, distinct categories, which, with increasing elaboration, describe the act of using digital technologies for teaching as (i) accumulating subject content for passing on to students for learning; (ii) motivating and accommodating students to understand subject content in learning; (iii) building a positive teacher-student rapport in extending students' learning; (iv) modeling behavior inspiring students to technology mediated explorative learning and (v) fostering a community of learners participating and convening dialogic learning. Figure 1 also shows the predominant discernment for each category. As will be elaborated further on, the distinct categories are configured as structurally tied together by three critical dimensions of deepening discernment. Acknowledging the analogue nature of deepening discernment, seemingly paradoxical, the distinct categories simultaneously come together seamlessly to form a complete picture.

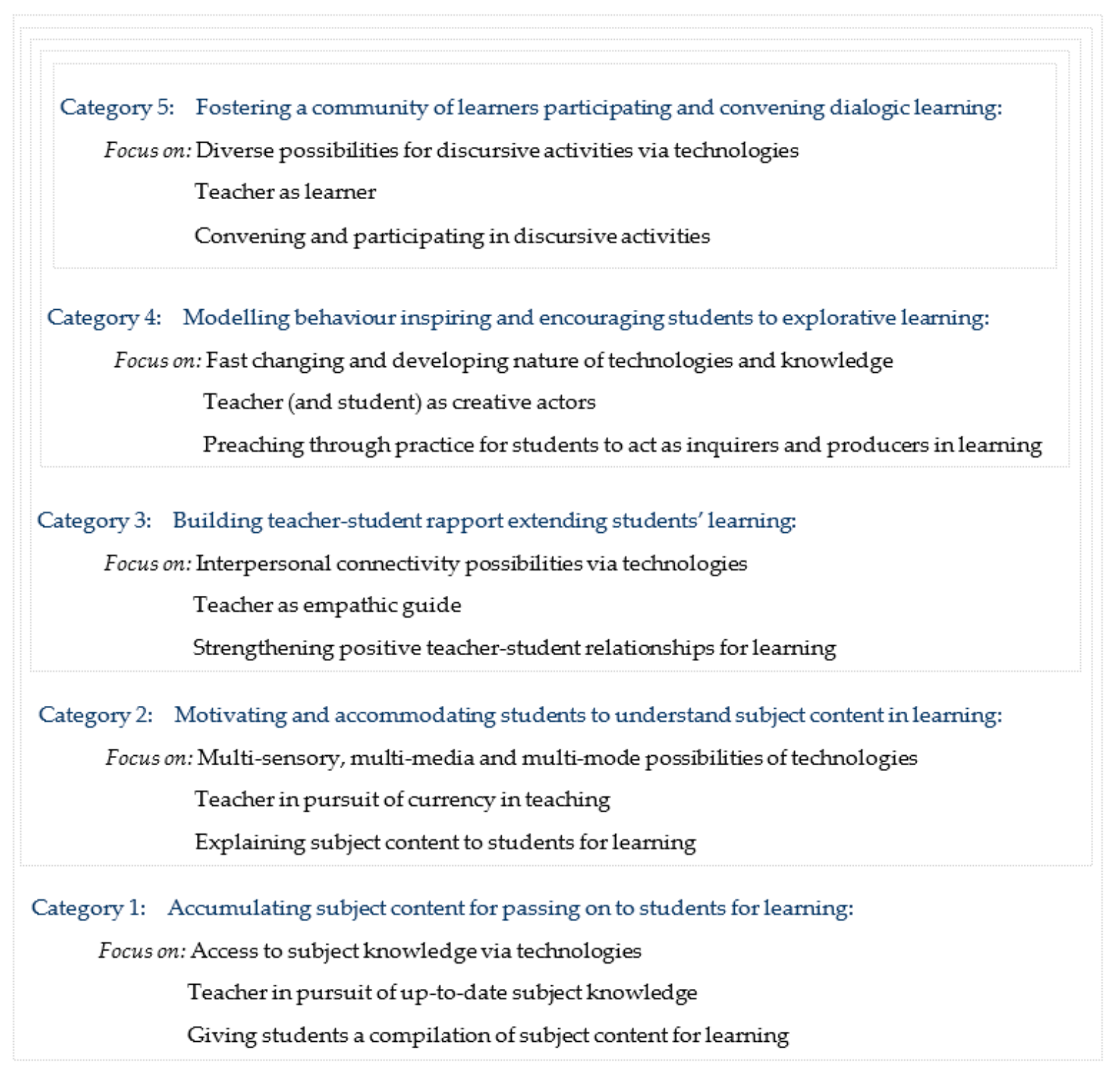

Figure 1. The constitution of experience: Using digital technologies for higher education teaching. 


\subsubsection{Category 1}

Academics of this category acknowledge digital technologies as significant contemporary tools. Particularly they foreground the Internet as a massive library. The Internet is recognized as very useful for looking up information when preparing lecture notes to be directly or indirectly shared with students for learning purposes. The intention is to help the students by providing them with a compilation of up-to-date study content. It might be that the academic aligning to this category uses asynchronous communication possibilities (such as short messaging service or electronic mail) in teaching practice. These communication media are used for teaching process purposes such as lecture cancellation alerts, reminders of due assessment work, or in responding to the occasional email sent by a student. Generally, digital technologies are used for teaching as much as they help make established knowledge dissemination practices more efficient in distinction from their use in teaching as the case of more elaborate interpretations:

"I am preparing my lesson ... Today I'd rather than go to the library look it up in the [online spaces such as] Stanford Encyclopedia of Philosophy for instance, or Google Scholar for instance. Because physically it's easier than, you know, going to the library, whatever. Moreover, the availability of resources is obviously bigger" (\#19).

\subsubsection{Category 2}

The academic aligning to this category foregrounds the multi-sensory, multi-media and multi-mode possibilities of available technologies. This leads the academic to see the usefulness of technologies for motivating students to engage in learning activity, to make learning fun, exciting and easier to cope with. The intention is "to spark off" (\#27) students' interest, to explain subject content to students and to help them understand it. Through digital technologies, the academic aligning to this category is actively seeking to motivate and to facilitate students' understanding of subject content moreover the effort to access, accumulate and disseminate it to students as in the previous category. Aligning to this category academics acknowledge the unavoidability of digital technologies, which have become "part and parcel" (\#23) to teaching and research practices. They feel pressured to show themselves current in digital technology use but are not inclined to reach out to the students by "bending to their culture" (\#15) as academics aligning to more elaborate categories in using digital technologies for teaching:

"My intention is to make knowledge more understandable and to make learning more meaningful. It has to be more meaningful in the sense that they can see something that is abstract, as I show a simulation for example. It can help in that sense. And it is also to show others-I have never thought of it this way, I don't know but-others have to know that you are literate in this camp because that way it is going to improve their sense of becoming more literate" (\#27).

\subsubsection{Category 3}

The academic aligning to this category is also foregrounding the importance of a positive teacher-student rapport for improving students' learning. Connecting to students through the technologies they prefer is a means for strengthening the teacher-student rapport, which is key to motivating students' engagement for learning. The intention is to enthuse students to actively pursue learning and extend provision and connectedness with the teacher using technologies. The diversity of digital technologies and media is seen facilitating the response to students' different needs, styles and preferences moreover being a means for connecting to students, hence accentuating a "caring" (\#15) perspective. As with the earlier categories, there is a concern to convey subject content to students but now there is a distinctive intention to put the students' "mind at rest" $(\# 15, \# 22)$. As for the case of the previous category, this academic is also concerned motivating and supporting students' understanding of subject content. Additionally, the academic seeks to remain in contact with students for just-in-time responding to their learning needs. The academic uses digital technologies to encourage, guide and monitor students in active pursuit for learning what has to be learnt. However, markedly, the academic 
continues to attend to the teacher-student relationship overlooking student-student relations for learning. Different from the attitude in aligning to more elaborate categories, the academic is reactively rather than proactively encouraging a participatory culture for learning:

"My understanding is that these technologies improve access to learning even for persons with disabilities, for people with different learning difficulties. It's a way of access, enhancing learning and extending learning. That is what I understand. Also, to build on even the social rapport. It extends learning both as an academic for what you need to know, but even on one-to-one as a teacher to help you understand learning, or support you in whatever. For example, they like the idea of having a Facebook page. I didn't have even Facebook myself. I didn't know of it. I said, "Fine, I'll do whatever you want" I tell them. I don't kill it. "Only make sure that you are very sensitive on what you put". I always say that because it is my responsibility as an educator to always make sure things are useful, are with the right principles, you know. The idea of sending good values is cross-sectional. It's across [the board] and it comes instinctively to me I see myself as a caregiver" (\#15).

\subsubsection{Category 4}

Further to understandings and approaches described by previous categories of description, academics aligning to this category take it upon themselves to create teaching episodes demonstrating the seamless integration of contemporary digital technologies for learning, and prompting students to do the same in their learning practices. The intention is "preaching through practice". The academic is now proactively focusing on being a "performer" and an "animator, coach, mentor and tutor"(\#1) in online spaces as well as in offline spaces. The students are projected as active participants sharing the stage of the teaching and learning process as creative producers too. Subject content is promoted as a means for learning rather than an end-it is "almost an excuse" and "tomorrow will be obsolete" (\#6). Using digital technologies in teaching is interpreted as an "eye-opener" (\#1) for students as well as for the teacher because the teacher's thinking about teaching is in a dynamic process of development too. As for the case of previous categories, available digital technologies are recognized as significant tools for accessing information and for facilitating understanding of subject content. However, distinctively, access to information is now seen as just-in-time when required, and facilitation to understanding subject content is an integral aspect of explorative learning activity. Ongoing two-way communication is now encouraged between students for mutually supporting each other's learning moreover the communication with the teacher as in the previous category. The academic is now actively seeking to "transmit a culture" using "malleable technologies" (\#1) to address the problem of knowledge volatility. The academic is now discerningly employing student-centered pedagogical approaches leading students to explorative learning:

"My approaches are not to always use the same technology, the same platform, or to pick up on one (technology) and always the same, but to adapt. First of all, I adapt to the people who are in front of me, that's first and foremost. Secondly, to use a number of technologies, and rather than using them myself, to encourage my students to use a number of different technologies, to discover (learning) technologies for themselves. More than the technologies, their application for reaching their objectives. I mean there are occasions when the students discover (technological) tools which I don't even know about. And he tells me for example "I found that very useful. Really good. I'm really using it well. I really used it during the teaching practice. I really enjoyed it." And I like that as well because it wasn't me who told him, but through certain approaches which we used in class, he is able to discover tools and make them his own" (\#18).

\subsubsection{Category 5}

The academic aligning to this category of description foregrounds discursive activities and collaboration for learning. The academic discerns the potential of digital technologies for discursive activity, so a means for fostering "a community of learners" (\#8,\#9) with students. Digital technologies are seen permitting collaborative engagement including inter-student conversations, discussion and 
debate. The intention is to encourage the development of students' higher order skills such as critical, analytical and leadership skills. In teaching the focus is on dialogic learning "pushing" the students "to go beyond the basic", encouraging debate among students, cheering them to "argue" and "fight" with each other for learning (\#8). Academics aligning to this category foreground themselves as learners more openly than was the case in aligning to the previous category. They also see themselves learning from the questions and the shared experiences of students. They admit that at times students come up with issues that are "challenging for me as well" (\#5) The teacher is projected as a member of the community of learners that $\mathrm{s} /$ he is seeking to foster using whatever technologies best fit purpose:

"So, first is warming up exercises. It might be a virtual cork board. It might be simple from name your hero to something silly, or "What are your three objectives?", "What would you like to learn through this study unit?". You know, we do that to get them to communicate and get them to start to create that community of learners basically the study-unit might have a week of reading only. Or two weeks of reading only. So we would provide the students with specific reading material and then the following period would be four weeks of very intensive critical discussions which the lecturer will lead but also be a member of and participate" (\#8).

\subsection{The Attempt to Interpret and Portray Discernment}

The act of using digital technologies for HE teaching is described as expanding from compiling up-to-date information for students to study, to sparking off students' understanding and accommodating them to engage with subject content, to pursuing a positive teacher-student rapport motivating student engagement for learning, to leading students espousing student-centered learning approaches, to fostering a learning network wherein the lead teacher and students cooperate, collaborate and co-create. In aligning to Category 1 , the academic focuses on the access to subject knowledge via technologies, the teacher as in pursuit of up-to-date subject knowledge, and the act of giving students a compilation of subject content to study. In aligning to Category 2, the academic also focuses on the multi-sensory, multi-media and multi-mode possibilities of technologies, the teacher as in pursuit of currency in teaching, and the act of explaining subject content to students for learning. In aligning to Category 3 , the academic also focuses on the interpersonal connectivity possibilities via technologies, the teacher as empathic guide, and the act of strengthening the teacher-student rapport so possibly encouraging learning engagement. In aligning to Category 4 , the academic also focuses on the fast changing and developing nature of digital technologies and knowledge, the teacher (and students) as creative actors, and the act of preaching through practice for students to act as inquirers and producers in learning. In aligning to Category 5 , the academic also focuses on the diverse possibilities of digital technologies for discussion and networking, the teacher as learner too, and the act of convening and participating in discursive activities. The focal elements associated with the categories of description signify specific values along the dimensions of deepening awareness, which, for the case of this study, were configured by (i) perceived possibilities of technology use for teaching (and learning), (ii) perceived teacher (and student) roles in teaching (and learning), and assumed pedagogical strategies for teaching (and learning). Table 1 clarifies how the focal elements for each of the distinct categories were brought together to constitute these critical dimensions of deepening discernment. In turn, these critical dimensions of deepening discernment bring together the categories of description to form a single whole picture. Going from top to bottom along each of the three columns of Table 1 is a continuum of deepening discernment even if, for the purposes of the neat phenomenographic representation, the in-category and between-category messiness is deliberately suspended. In other words, variation in the constitution of experience is fuzzy and analogue in nature even if interpretatively we project it as comprised of differentiated parts and whole. 
Table 1. Critical dimensions of deepening discernment.

\begin{tabular}{|c|c|c|c|}
\hline & Affordances of Technology & Human Roles & $\begin{array}{c}\text { Digitally Enhanced Pedagogical } \\
\text { Strategy }\end{array}$ \\
\hline Category 5 & $\begin{array}{l}\text { Diverse possibilities for } \\
\text { discussions (networking) via } \\
\text { technologies }\end{array}$ & Teacher as learner & $\begin{array}{l}\text { Discursive learning activity } \\
\text { engagement with students }\end{array}$ \\
\hline Category 4 & $\begin{array}{c}\text { Fast development of } \\
\text { technologies and knowledge }\end{array}$ & $\begin{array}{c}\text { Teacher as creative } \\
\text { actor }\end{array}$ & $\begin{array}{l}\text { Explorative learning activity with } \\
\text { students acting as inquirers }\end{array}$ \\
\hline Category 3 & $\begin{array}{c}\text { Interpersonal connectivity } \\
\text { possibilities via technologies }\end{array}$ & $\begin{array}{l}\text { Teacher as empathic } \\
\text { guide }\end{array}$ & $\begin{array}{l}\text { Strengthening the teacher-student } \\
\text { rapport for learning engagement }\end{array}$ \\
\hline Category 2 & $\begin{array}{l}\text { Multi-sensory, multi-media } \\
\text { and multi-mode possibilities } \\
\text { of technologies }\end{array}$ & $\begin{array}{l}\text { Teacher in pursuit of } \\
\text { currency in teaching }\end{array}$ & $\begin{array}{l}\text { Explaining subject content to } \\
\text { students for learning }\end{array}$ \\
\hline Category 1 & $\begin{array}{c}\text { Access to subject knowledge } \\
\text { via technology }\end{array}$ & $\begin{array}{c}\text { Teacher in pursuit of } \\
\text { up-to-date subject } \\
\text { knowledge }\end{array}$ & $\begin{array}{l}\text { Giving students a compilation of } \\
\text { subject content to study }\end{array}$ \\
\hline
\end{tabular}

\section{Transcending the Popular Transmission-as-Opposed-to-Participation Teaching Perspective}

These research findings mapping out qualitative distinctions in the constitution of experience using digital technologies for HE teaching emphasize a pluralistic perspective of variability. There is acknowledgement that different academics, and indeed the same academic in different situations spatially and/or temporally, potentially understand and approach teaching differently. Distinct ways of experiencing digital technologies for teaching are presented as alternatives shaped by thematic awareness in specific situations. Critically they are determined by degrees of discernment with regards to technology affordances for teaching, teaching approach possibilities and possibilities of human roles for teaching.

These findings generally confirm earlier research results but they are seen adding to them too. The experience of digital technologies for HE teaching as a means to build the teacher-student rapport for the support of learning is a first in consideration of unearthed previous studies. An even more significant contribution relates to the popular transmission-as-opposed-to-participation teaching perspective. These research findings confirm the transmission and participation orientations when incorporating contemporary digital technologies for teaching. If one takes a step back, there is detectable between category 3 and category 4 a watershed subdividing the phenomenographic space into two main clusters confirming the transmission and the participation teaching orientations. Whereas the first three categories can be seen as advancing a transmission attitude, correspondingly transmission of information, transmission of understanding and transmission of a caring attitude, the two most elaborate categories advance a participation attitude, correspondingly participation in creative exploration and sharing, and participation in discursive and community collaboration. However, considering these results in the light of the phenomenographic frame of reference, these five distinct categories of description are not constituted as independent. Together they form a map of the constitution of experience. An elaborate way of understanding and approaching teaching using digital technologies encompasses less elaborate standpoints. Besides, the recognition of experiencing as temporally and situationally bounded, all the more leads one to conclude that in the contemporary digital university, teaching as transmission and teaching as participation need to be valued as both significant facets of teaching. Furthermore, according to the research outcome of this phenomenographic study, the degree of transmission and of participation enacted is influenced by perceived technology affordances for teaching, perceived human roles for teaching and assumed pedagogical strategies for teaching and associated learning. 


\section{Beyond Transmission and Participation for Teaching Development}

These research findings potentially serve initiatives to improve and constructively support the development of teaching at the digital university. As a wide-ranging description of the experience incorporating digital technologies in HE teaching, these findings inspire contemplative and active inquiry attitudes for academic development discouraging prescription. The phenomenographic map can be used as a basis for individual or collective reflection on teaching practice and/or the appraisal of instances of teaching episodes for the purpose of planning future teaching enterprise. The three dimensions of deepening discernment also permit the focus of reflective and critical action to be narrowed down permitting in depth scrutiny of specific teaching practice aspects. The three critical dimensions of deepening discernment also invite the adoption of variation theory $[45,48]$ as a learning approach for professional development enterprise. In this case, teaching episodes are planned for permitting learners to systematically experience variation along the distinct critical dimensions in separation, in contrast and in fusion [45]. The experience of variation in what appears to critically matter in the use of digital technologies for teaching potentially triggers deepening discernment, and possibly the desired teaching development.

\section{Conclusions}

The purpose of this paper was to share a new research-generated description for understanding the academic's experience incorporating contemporary digital technologies for teaching. This phenomenographic description of variation generally confirms previous research results and adds to them. Particularly it highlights the multidimensionality of the constitution of experiencing teaching using digital technologies over and above the multilayering. The comprehensive perspective presented by this phenomenographic map of variation provides a means for appreciating transmission and participation oriented teaching practices as complementing each other, moreover existing claims based on logical argumentation. One does not exclude the other, and one is not in contrast to the other. Discerned thematic elements of the teaching situation steer the teaching. According to these phenomenographic research findings, teaching using digital technologies is understood and approached critically affected by the perceived technology affordances for teaching, the alternative pedagogical strategies to teaching, and human role possibilities in teaching.

As with other phenomenographic mappings, these research results need to be acknowledged that they are an open-ended depiction. As research outcomes, they are best suited for use in the context from which they were constituted [49]. Nonetheless, in general they contribute to the emerging picture representing the incorporation of contemporary digital technologies for teaching.

These research results come just in time when academics are increasingly engaging with digital technologies for taking forward their professional practices, and at the same time HE institutions are providing more professional development opportunities for academics to access support for improving their teaching with digital technologies. In their capacity advancing a current wide-ranging map representing the constitution of the experience using digital technologies for teaching, these research results possibly help to inspire positive evolution rather than disruptive change. Potentially they provide a constructive means for supporting individual and collective professional development initiatives. Calls by policy makers within the institution and beyond, echoing the appeals of enthusiastic educational technology forerunners for the disruption and transformation of teaching and the need to foster 21st century skills, may all be in good faith. However, inadvertently these calls create disheartening pressure not so much expedient to higher education as a "public good" [33] and supposedly a constructive generator of learning networks spanning across the institution, the national, international and transnational realms at large. In consideration of today's technology imbued settings (enfolding seamless entanglements of human and non-human constituents), an expansive perspective such as generated by this explorative study serves as an invitation to rise above the hype, for incorporating contemporary digital technologies that are already very much part of our lives as best fit and serve purpose in our teaching practices too. 
Funding: This research was in part funded by a University of Malta grant (Reference Number: ORXRP01-16).

Conflicts of Interest: The author declares no conflict of interest. The funders had no role in the design of the study; in the collection, analyses, or interpretation of data; in the writing of the manuscript, or in the decision to publish the results.

\section{References}

1. Jandrić, P.; Knox, J.; Besley, T.; Ryberg, T.; Suoranta, J.; Hayes, S. Postdigital science and education. Educ. Philos. Theory 2018, 50, 893-899. [CrossRef]

2. Walker, R.; Voce, J.; Jenkins, M. Charting the development of technology-enhanced learning developments across the UK higher education sector: A longitudinal perspective (2001-2012). Interact. Learn. Environ. 2016, 24, 438-455. [CrossRef]

3. Siemens, G.; Gašević, D.; Dawson, S. Preparing for the Digital University: A Review of the History and Current State of Distance, Blended, and Online Learning; Link Research Lab.: Arlington, VA, USA, 2015.

4. Kirkwood, A.; Price, L. Missing: Evidence of a scholarly approach to teaching and learning with technology in higher education. Teach. High. Educ. 2013, 18, 327-337. [CrossRef]

5. Jones, C.; Asensio, M. Designs for networked learning in higher education: A phenomenographic investigation of practitioners' accounts of design. In Networked Learning: Perspectives and Issues; Steeples, C., Jones, C., Eds.; Springer: London, UK, 2002.

6. Weller, M. Delivering Learning on the Net; RoutledgeFalmer: London, UK, 2002.

7. McLoughlin, C.; Lee, M.J.W. Future Learning Landscapes: Transforming Pedagogy through Social Software. Innov. J. Online Educ. 2008, 4, 1. Available online: https://nsuworks.nova.edu/innovate/vol4/iss5/1/ (accessed on 27 August 2019).

8. Harasim, L. Learning Theory and Online Technologies, 2nd ed.; Routledge: New York, NY, USA, 2017.

9. Bates, T. Teaching in a Digital Age; Tony Bates Associates Ltd.: Vancouver, BC, Canada, 2015.

10. Zhao, Y. The Changing Context of Teaching and Implications for Teacher Education. Peabody J. Educ. 2018, 93, 295-308. [CrossRef]

11. Roberts, G. Teaching using the web: Conceptions and approaches from a phenomenographic perspective. Instr. Sci. 2003, 31, 127-150. [CrossRef]

12. Rienties, B.; Brouwer, N.; Lygo-Baker, S. The effects of online professional development on higher education teachers' beliefs and intentions towards learning facilitation and technology. Teach. Teach. Educ. 2013, 29, $122-131$. [CrossRef]

13. Kirkwood, A.; Price, L. Technology-enhanced learning and teaching in higher education: What is 'enhanced' and how do we know? A critical literature review. Learn. Media Technol. 2014, 39, 6-36. [CrossRef]

14. Sfard, A. On Two Metaphors for Learning and the Dangers of Choosing Just One. Educ. Res. 1998, $27,4-13$. [CrossRef]

15. Biesta, G. Receiving the gift of teaching: From 'learning from' to 'being taught by'. Stud. Philos. Educ. 2013, 32, 449-461. [CrossRef]

16. Selwyn, N. Education and Technology: Key Issues and Debates, 2nd ed.; Bloomsbury Publishing: London, UK, 2017.

17. Gourlay, L.; Oliver, M. Student Engagement in the Digital University; Routledge: New York, NY, USA; Oxon, UK, 2018.

18. Eynon, R.; Salveson, C. Mapping AI and Education Debates: Revisiting acquisition and participation metaphors for learning. Proceedings of International Conference on Networked Learning, Zagreb, Croatia, 14-16 May 2018.

19. Cutajar, M. Teachers' experiences using networked technologies for teaching. Proceedings of Eleventh International Conference on Networked Learning, Zagreb, Croatia, 14-16 May 2018.

20. Cutajar, M. Higher Education Teachers' Experiences of Networked Technologies for Teaching; Malta University Publishing: Msida, Malta, 2018.

21. Goodyear, P.; Carvalho, L. Networked Learning and Learning Networks. In The Architecture of Productive Learning Networks; Calvalho, L., Goodyear, P., Eds.; Routledge: New York, NY, USA; Oxon, UK, 2014.

22. Jones, C. Experience and Networked Learning. In Networked Learning: Reflections and Challenges; Bonderup, D.N., Cranmer, S., Sime, J., de Laat, M., Ryberg, T., Eds.; Springer: Cham, Switzerland, 2018. 
23. Beetham, H.; Sharpe, R. Introduction to Rethinking Pedagogy. In Rethinking Pedagogy for a Digital Age, 2nd ed.; Beetham, H., Sharpe, R., Eds.; Routledge: New York, NY, USA, 2013.

24. Goodyear, P. Psychological Foundations of Networked Learning. In Networked Learning: Perspectives and Issues; Steeples, C., Jones, C., Eds.; Springer: London, UK, 2002.

25. Laurillard, D. Rethinking University Teaching: A Framework for the Effective Use of Learning Technologies, 2nd ed.; RoutledgeFarmer: Oxon, UK, 2002.

26. Bryant, A. Web 2.0: A New Wave of Innovation for Teaching and Learning? Educause Rev. 2006, 41, 32-44.

27. Downes, S. E-learning 2.0. Elearn Mag. 2005, 41, 32-44.

28. Siemens, G. Learning and knowing in networks: Changing roles for educators and designers. ITFORUM Discuss. 2008, 27, 1-26.

29. Jenkins, H.; Ito, M.; Boyd, D. Participatory Culture in a Networked Era: A Conversation on Youth, Learning, Commerce, and Politics; Polity: Cambridge, UK, 2016.

30. Healey, M.; Flint, A.; Harrington, K. Engagement through Partnership: Students as Partners in Learning and Teaching in Higher Education; HE Academy: York, UK, 2014.

31. Healey, M.; Flint, A.; Harrington, K. Students as partners: Reflections on a conceptual model. Teaching $\mathcal{E}$ Learning Inquiry 2016, 4, 1-13.

32. Deeley, S.J.; Bovill, C. Staff student partnership in assessment: Enhancing assessment literacy through democratic practices. Assess. Eval. High. Educ. 2017, 42, 463-477. [CrossRef]

33. Johnston, B.; Macniell, S.; Smyth, K. Conceptualising the Digital University; Palgrave Macmillan: Cham, Switzerland, 2018.

34. Bowden, J. The nature of phenomenographic research. In Phenomenography; Bowden, J., Walsh, E., Eds.; RMIT University Press: Melbourne, VIC, Australia, 2000.

35. Bowden, J.A.; Green, P. (Eds.) Doing Developmental Phenomenography; RMIT University Press: Melbourne, VIC, Australia, 2005.

36. Lameras, P.; Levy, P.; Paraskakis, I.; Webber, S. Blended university teaching using virtual learning environments: Conceptions and approaches. Instr. Sci. 2012, 40, 141-157. [CrossRef]

37. Shah, U. Teacher's Use of Learning Technology in a South Asian Context. In The Design, Experience and Practice of Networked Learning; Hodgson, V., De Laat, M., McConnell, D., Ryberg, T., Eds.; Springer International Publishing Switzerland: Cham, Switzerland, 2014.

38. Khan, S.H. Emerging conceptions of ICT-enhanced teaching: Australian TAFE context. Instr. Sci. 2015, 43, 683-708. [CrossRef]

39. Kim, C.; Kim, M.K.; Lee, C.; Spector, J.M.; DeMeester, K. Teacher beliefs and technology integration. Teach. Teach. Educ. 2013, 29, 76-85. [CrossRef]

40. Waight, N.; Liu, X.; Gregorius, R.M.; Smith, E.; Park, M. Teacher Conceptions and Approaches Associated with an Immersive Instructional Implementation of Computer-Based Models and Assessment in a Secondary Chemistry Classroom. Int. J. Sci. Educ. 2014, 36, 467-505. [CrossRef]

41. González, C. The relationship between approaches to teaching, approaches to e-teaching and perceptions of the teaching situation in relation to e-learning among higher education teachers. Instr. Sci. 2011, 40, 975-998. [CrossRef]

42. Souleles, N. Phenomenography and elearning in art and design. Proceedings of 8th International Conference on Networked Learning, Maastricht, The Netherlands, 2-4 April 2012.

43. Prosser, M.; Trigwell, K. Understanding Learning and Teaching; SRHE and Open University Press: Buckingham, UK, 1999.

44. Marton, F. Cognosco ergo sum-Reflections on reflections. In Reflections on Phenomenography; Dall'Alba, G., Hasselgren, B., Eds.; Acta Universitatis Gothonburgensis: Gothenburg, Sweden, 1996.

45. Marton, F. Necessary Conditions of Learning; Routledge: New York, NY, USA; Oxon, UK, 2015.

46. Marton, F.; Booth, S. Learning and Awareness; Lawrence Erlbaum: Hillsdale, NJ, USA, 1997.

47. Åkerlind, G.S. Variation and commonality in phenomenographic research methods. High. Educ. Res. Dev. 2005, 24, 321-334. [CrossRef] 
48. Marton, F.; Runesson, U.; Tsui, A.B.M. The Space of Learning. In Classroom Discourse and the Space of Learning; Marton, F., Tsui, A.B.M., Eds.; Routledge: New York, NY, USA; London, UK, 2004.

49. Bowden, J. Reflections on the phenomenographic team research process. In Doing Developmental Phenomenography; Bowden, J., Green, P., Eds.; RMIT University Press: Melbourne, VIC, Australia, 2005.

(C) 2019 by the author. Licensee MDPI, Basel, Switzerland. This article is an open access article distributed under the terms and conditions of the Creative Commons Attribution (CC BY) license (http://creativecommons.org/licenses/by/4.0/). 